\title{
Foreword to the
}

\section{English Translation}

by Peggy Kamuf

Fourteen of the twenty-three interviews collected in this volume appear here for the first time translated into English. Of the remaining interviews, one, "Heidegger, the Philosophers' Hell," has been retranslated for this edition. The interview titled "The Work of Intellectuals and the Press (The Bad Example: How the New York Review of Books and Company Do Business)" was specially commissioned for this volume, and one other previously translated interview, "Honoris Causa: 'This is also extremely funny," has been added to those collected in the original French edition. The circumstances in which the interviews were given and the dates and places of their first publication (or their broadcast, in the case of radio interviews) are described by the initial note accompanying each text.

Besides this initial note, other notes have been added to many of the interviews, either by the editor of the collection, Elisabeth Weber, or by the translator. Translator's notes are identified by "-Trans." at the end of the note; author's notes are identified by "-J.D." All other notes are the editor's. In the text and notes, square brackets indicate an insertion made by the editor or translator, except in "Between Brackets I" and "Ja, or the faux-bond II," where square brackets are used by Derrida and curly brackets by the editor or translator. Complete bibliographical information for 
works by Derrida frequently referred to in the text of the interviews or in the notes is listed at the end of the volume.

A word about the translation of the original title, Points de suspension. This expression commonly refers to the punctuation mark called suspension points in English. But as Elisabeth Weber explains in her introduction, the expression, in its position as title of a collection of interviews, gets overwritten or re-marked by a more "literal" sense of points of suspension, punctual interventions suspended from, for example, the other's discourse and often interrupted by an interlocutor. Hence the graphic solution chosen to translate, for the eye and the ear, this double title. The three dots (set close together: ...) will also frequently punctuate the suspended remarks of Derrida and his interlocutors. An ellipsis, or three spaced dots (...) will be used to indicate any omissions.

Finally, a word of gratitude to the other translators whose work is reprinted here. It is often said that translation is a thankless task, which is true enough if one means that it is, by definition and in advance, doomed to a kind of failure since it can do no more than approximate the original. Translators of Derrida's writings have the additional awareness that this failure is often actively anticipated and aggravated by the language of the original and by a thinking that, at every turn, seeks something like its idiom. That added awareness, however, need not be counted as a negative or a handicap when figured into the experience; on the contrary, these texts, in their consideration of and for translation's impossibility (and therefore its necessity) can reconfigure "thanklessness" or "ingratitude" in a wholly different economy of meaning and experience. In any case, if it takes one translator to recognize and appreciate the work of others, then let that be the case here. Namely:

Christie V. McDonald, for "Choreographies," originally published in Diacritics 12, no. 2 (1982): 66-76, and reprinted by permission of Johns Hopkins University Press.

Verena Andermatt Conley, for "Voice II," originally published in boundary 2, 19:2. Translation (C) 1984 by Verena Conley. Reprinted by permission of Duke University Press. 
John P. Leavey, Jr., for “Comment donner raison?'How to Concede, with Reasons?" " originally published in Diacritics 19, nos. 3-4 (1989): 4-9, and reprinted by permission of Johns Hopkins University Press.

Michael Israel, for "The Rhetoric of Drugs," originally published in differences: A Journal of Feminist Cultural Studies 5.I (1993): I24.

Peter Connor and Avital Ronell, for " 'Eating Well,' or the Calculation of the Subject," originally published in Topoi 7, no. 2 (1988): II3-2I, and reprinted by permission of Kluwer Academic Publishers.

Marian Hobson and Christopher Johnson, for "Honoris Causa: 'This is also extremely funny,' " originally published in the Cambridge Review I13, no. 2318 (October 1992), and reprinted by permission of Cambridge University Press.

All other translations are mine. The translation of Che $\cos ^{\prime} \grave{e} l a$ poesia? first appeared in A Derrida Reader: Between the Blinds, Peggy Kamuf, ed., 199I (C) Columbia University Press, New York. Reprinted with permission of the publisher.

We thank the publishers for their kind permission to reprint. Whatever modifications may have been made occasionally to these translations were adopted to regularize usage and vocabulary across the volume. 
